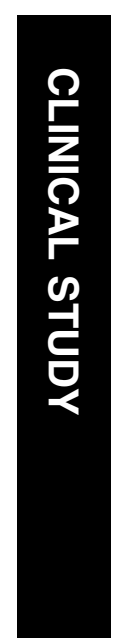

\title{
External ocular infections due to methicillin-resistant Staphylococcus aureus (MRSA)
}

\begin{abstract}
Purpose To determine the prevalence and clinical characteristics of external ocular infections caused by methicillin-resistant Staphylococcus aureus (MRSA) in an ophthalmic hospital in the UK.
\end{abstract}

Methods A retrospective analysis of the case notes of patients who had culture proven external ocular Staphylococcal infections during a 44-month period was undertaken. Results There were a total of 548 external eye ${ }^{1}$ Manchester Royal Eye Hospital Manchester UK

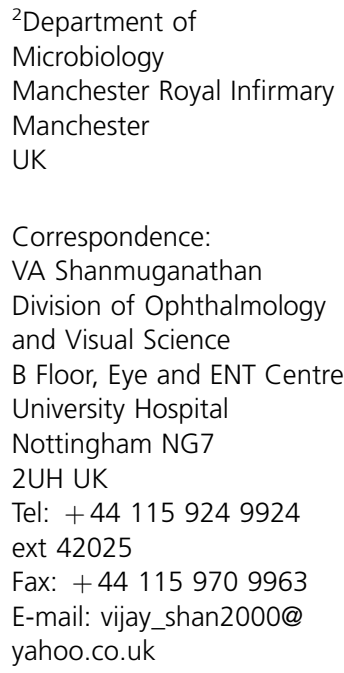

Correspondence: VA Shanmuganathan Division of Ophthalmology and Visual Science B Floor, Eye and ENT Centre University Hospital Nottingham NG7 2UH UK

Tel: +44 1159249924

ext 42025

Fax: + 441159709963

E-mail: vijay_shan2000@

yahoo.co.uk

Received: 23 June 2003 Accepted: 29 December 2003

Published online: 17

September 2004

This study was presented in part as a poster at The Royal College of Ophthalmologists Annual Congress,

Manchester, UK, May 2002. infections caused by Staphylococcus aureus. Of these, 17 (3\%) were MRSA positive. The most common presentation was conjunctivitis seen in six patients. All MRSA isolates were sensitive to chloramphenicol. Ofloxacin resistance was observed in all isolates from patients over the age of 50 years. All patients had an underlying history of either an ocular surface disease, malignancy, or a debilitating medical illness. Conclusions MRSA is as yet an infrequent cause of external ocular infections. Patients typically have underlying ocular risk factors and/or are medically debilitated. Different strains infect young and old age groups with characteristic antimicrobial sensitivity. This study highlights the need for more work to establish the role of MRSA commensals and ocular infections.

Eye (2005) 19, 284-291. doi:10.1038/sj.eye.6701465

Published online 17 September 2004

Keywords: MRSA; keratitis; conjunctivitis; dacrocystitis; ocular infection

\section{Introduction}

The term methicillin-resistant Staphylococcus aureus (MRSA) was originally used to describe Staphylococcus aureus resistant to methicillin. As
VA Shanmuganathan ${ }^{1}, \mathrm{M}$ Armstrong ${ }^{2}$, A Buller ${ }^{1}$ and AB Tullo' methicillin is rarely used in testing laboratories nowadays, the term is now used to describe strains of $S$. aureus resistant to all $\beta$-lactam antimicrobials.

As a result of its multiple drug resistance and its increasing prevalence, MRSA is a serious cause of morbidity and mortality worldwide. ${ }^{1}$ Outbreaks of infections have posed difficult challenges for those involved in infection control. Certain hospitals and indeed countries have adopted very robust measures to control the spread of MRSA, the so-called 'search and destroy' policies, whereas others have realised the limitations of the resources available to tackle the problem and have adopted less stringent controls. $^{2}$

Much has been written on the subject of MRSA and its epidemiology, ${ }^{3}$ but until recently, there has been a paucity of information relating MRSA to eye disease. We wished to determine the prevalence and clinical characteristics of external eye infections by MRSA in a large British eye unit. In addition, we aimed to establish the underlying antimicrobial sensitivities of the MRSA strains and any associated patient characteristics.

Patients and methods

Using a microbiological database, patients who had MRSA cultured from either a conjunctival swab or a corneal scrape were identified and had their case notes examined retrospectively. We used the same database to determine if screening for MRSA in nonocular sites had been carried out in these patients. We defined the term external ocular infections to include the following structures: the ocular surface, the nasolacrimal system, eyelids, and any conjunctiva in 'empty' sockets. The corneal scrapes that were performed used a 21-gauge needle which was then inoculated onto a 
chocolate and blood agar culture plate, agar blobs for enrichment, and a glass slide for Gram staining in accordance with local protocols. ${ }^{4}$ The conjunctival swabs used were charcoal agar swabs. Sensitivity testing was performed in accordance to the British Society for Antimicrobials Chemotherapy (BSAC) guidelines. ${ }^{5}$

The cultures that were positive for bacteria were graded in terms of the intensity of their growth: heavy $(+++)$, moderate $(++)$, light $(+)$, and scanty $(+/-)$. In several cases, there was growth of more than one organism, and we defined MRSA as a commensal when the growth of the significant pathogen was 2 or 3 ' + 's greater than MRSA on the scale described above.

\section{Results}

There were 548 external ocular infections caused by S. aureus over a 44-month period (1997-2001), of which $17(3 \%)$ of the isolates were MRSA. The clinical details of the patients and antimicrobial sensitivities of the isolates are summarised in Table 1. The types of infections were as follows: conjunctivitis (six patients), keratitis (four patients), dacrocystitis (three patients), conjunctival socket infection (three patients), and one patient had a plomb abscess following retinal detachment surgery. In all, 13 patients were over 65 years and the other three under 25 years of age.

All patients had one or a combination of the following: malignancy, an underlying systemic debilitating disease, and a pre-existing history of an ocular surface disorder. Only five of the 17 patients were screened for evidence of MRSA in nonocular sites. This was positive in one patient.

All the MRSA isolates were sensitive to gentamicin and chloramphenicol. Only two of the isolates were sensitive to ofloxacin, both of which were in the younger age group.

\section{Discussion}

The majority of previous studies on MRSA ocular infections are from the USA and Japan and have been in the form of individual case reports, case series with small numbers, or descriptions of ocular infections within a part of an outbreak of MRSA (see Table 2). Recently, two centres from Japan have published more comprehensive work in this field looking at several aspects of MRSA ocular infections. ${ }^{6,7}$ Interesting comparisons of the cases in our study and that of previous work can be made.

Our study showed that MRSA external ocular infections were uncommon, representing only $3 \%$ of all the S. aureus external ocular infections. In Japan, Fukuda et al $^{7}$ demonstrated that of $115 \mathrm{~S}$. aureus isolates from patients with bacterial conjunctivitis, $74(64 \%)$ were
MRSA. An earlier study, also from Japan, put this figure at $25 \%$ but included all ocular infections and not just conjunctivitis. ${ }^{8}$ This illustrates the marked variation in the prevalence of MRSA ocular infections geographically and at different time points.

The type of infections described in previous studies are broadly the same, with conjunctivitis and keratitis the most common manifestations. The cases of keratitis we observed consisted of a minimal superficial defect with an associated subepithelial infiltrate and was nondestructive. Only in one case (patient no. 4) was there a frank ulcer and this was associated with marked superficial punctate erosions. Adenovirus was also cocultured and the infection healed without any serious sequelae with chloramphenicol treatment. These findings are similar to the majority of cases observed in a large series of MRSA and methicillin-resistant Staphylococcal epidermidis ocular surface infections. ${ }^{6}$ The authors proposed a four level grading system for the methicillinresistant keratitis, one being the mildest referring only to carriers and four for destructive keratitis leading to perforation. Three of the cases of isolated conjunctivitis in our series were noted to have a purulent discharge. There were no real or pseudomembranes reported on examination. In one case (patient no. 10), there were prominent papillae but this was likely to be secondary to atopic eye disease. The dacrocystitis in this series presented with an inflamed nasolacrimal swelling and discharge in two cases although this was only described as purulent in one case (patient no. 14). The same patient also had a delayed response to treatment presumably due to repeated infections. Thus, from our review, we could not establish any clear and specific signs on examination that indicated that the ocular infections were caused by MRSA.

Several patients in the above study who suffered from Stevens-Johnson syndrome and ocular cicatricial pemphigoid were considered to be 'ocular immunocompromised hosts.' Pre-existing ocular surface disease was seen in 10 of our patients, and dry eyes was the most common finding. This is not surprising as ocular surface disease is a significant risk factor for microbial keratitis. ${ }^{9}$

In our study, the spectrum of antibiotic sensitivity broadly fell into two groups: that seen in young and old patients. The strains affecting older patients were resistant to ofloxacin unlike two out of the three younger patients (patient nos. 9 and 10 in Table 1). The reasons behind this are not clear. All our cases were treated successfully and this was in part due to the universal efficacy of chloramphenicol, which was the most commonly used first-line topical antibiotic for external eye infections. The success of chloramphenicol as an effective agent against MRSA in the UK may be due to its 
Table 1 Summary of the clinical features of patients with MRSA external ocular infections

\begin{tabular}{|c|c|c|c|c|}
\hline No/age/sex & Previous ocular history & Type of ocular surface infection & $\begin{array}{l}\text { Sensitivities to } \\
\text { antimicrobials }\end{array}$ & Other medical details \\
\hline $1 / 70 / \mathrm{F}$ & Dry eyes & Purulent conjunctivitis & $\begin{array}{l}\mathrm{S}-\mathrm{CPL} / \mathrm{GENT} / \mathrm{FUS} \\
\mathrm{R}-\mathrm{CIP} / \mathrm{OXF} / \mathrm{CEF}\end{array}$ & $\begin{array}{l}\text { Rheumatoid arthritis/Sjogrens syndrome } \\
\text { Nursing home resident }\end{array}$ \\
\hline $2 / 80 / F$ & Dry eyes/entropion & Purulent conjunctivitis & $\begin{array}{l}\mathrm{S}-\mathrm{CPL} / \mathrm{GENT} / \mathrm{FUS} \\
\mathrm{R}-\mathrm{CIP} / \mathrm{OXF} / \mathrm{CEF}\end{array}$ & $\begin{array}{l}\text { COPD/Recurrent chest infections } \\
\text { Nursing home resident }\end{array}$ \\
\hline $3 / 69 / \mathrm{M}$ & Dry eye/trichiasis & Purulent conjunctivitis & $\begin{array}{l}\mathrm{S}-\mathrm{CPL} / \mathrm{GENT} / \mathrm{FUS} \\
\mathrm{R}-\mathrm{CIP} / \mathrm{OXF} / \mathrm{CEF}\end{array}$ & $\begin{array}{l}\text { COPD/Pneumonia } \\
\text { Positive for MRSA in nonocular sites }\end{array}$ \\
\hline $4 / 54 / \mathrm{M}$ & $\begin{array}{l}\text { Meibomianitis with associated tear film } \\
\text { dysfunction }\end{array}$ & $\begin{array}{l}\text { Keratitis-corneal ulcer. Adenovirus } \\
\text { also isolated }\end{array}$ & $\begin{array}{l}\mathrm{S}-\mathrm{CPL} / \mathrm{GENT} / \mathrm{FUS} \\
\mathrm{R}-\mathrm{CIP} / \mathrm{OXF} / \mathrm{CEF}\end{array}$ & Congestive cardiac failure/ascities/alcholism \\
\hline $5 / 67 / F$ & Herpes simplex keratitis & Conjunctivitis. H. influenzae also isolated & $\begin{array}{l}\mathrm{S}-\mathrm{CPL} / \mathrm{GENT} / \mathrm{FUS} \\
\mathrm{R}-\mathrm{OXF} / \mathrm{CEF}\end{array}$ & Asthma/hypertension \\
\hline $6 / 74 / \mathrm{M}$ & Streptococcus pneumoniae keratitis/HZO & Conjunctivitis. H. influenzae also isolated & $\begin{array}{l}\mathrm{S}-\mathrm{CPL} / \mathrm{GENT} / \mathrm{FUS} \\
\mathrm{R}-\mathrm{CIP} / \mathrm{OXF}\end{array}$ & COPD/systemic immunosuppression \\
\hline $7 / 85 / \mathrm{M}$ & Retinal detachment repair with a plomb & Plomb abcess and preseptal cellulitis & $\begin{array}{l}\mathrm{S}-\mathrm{CPL} / \mathrm{GENT} / \mathrm{FUS} \\
\mathrm{R}-\mathrm{OXF} / \mathrm{CEF}\end{array}$ & $\begin{array}{l}\text { Prostatic carcinoma, diverticulitis. } \\
\text { Negative for MRSA in other nonocular sites }\end{array}$ \\
\hline $8 / 67 / \mathrm{M}$ & Dry eyes & Keratitis & $\begin{array}{l}\mathrm{S}-\mathrm{CPL} / \mathrm{GENT} / \mathrm{FUS} \\
\mathrm{R}-\mathrm{OXF}\end{array}$ & $\begin{array}{l}\text { Myotonic dystrophy } \\
\text { Negative for MRSA in other nonocular sites } \\
\text { Nursing home patient }\end{array}$ \\
\hline $9 / 23 / \mathrm{M}$ & Contact lens wearer & Keratitis. Coliforms also isolated & $\begin{array}{l}\mathrm{S}-\mathrm{CPL} / \mathrm{GENT} / \mathrm{FUS} / \\
\mathrm{OXF} \\
\mathrm{R}-\mathrm{CEF}\end{array}$ & \\
\hline $10 / 16 / \mathrm{M}$ & Atopic conjunctivitis & Muco-purulent conjunctivitis & $\mathrm{S}-\mathrm{CPL} / \mathrm{GENT} / \mathrm{OXF}$ & Atopic patient on systemic immunosuppression \\
\hline $11 / 82 / \mathrm{F}$ & $\begin{array}{l}\text { Previous microbial keratitis/Band } \\
\text { keratopathy/HZO }\end{array}$ & Keratitis & $\begin{array}{l}\text { S CPL/GENT/FUS } \\
\text { R OXF/CEF }\end{array}$ & $\begin{array}{l}\text { NIDDM/CVA } \\
\text { Negative for MRSA in other nonocular sites }\end{array}$ \\
\hline $12 / 74 / \mathrm{M}$ & $\begin{array}{l}\text { Enucleation following pthsis from } \\
\text { neovascular glaucoma }\end{array}$ & Socket/Conjunctival infection & $\begin{array}{l}\text { S CPL/GENT/FUS } \\
\text { R OXF/CEF }\end{array}$ & COPD/NIDDM \\
\hline $13 / 71 / \mathrm{F}$ & Nil of note & Dacrocystitis & $\begin{array}{l}\mathrm{S}-\mathrm{CPL} / \mathrm{GENT} / \mathrm{FUS} \\
\mathrm{R}-\mathrm{OXF} / \mathrm{CEF} /\end{array}$ & $\begin{array}{l}\text { Lymphoma } \\
\text { Negative for MRSA in other nonocular sites }\end{array}$ \\
\hline
\end{tabular}


limited use systemically for nonocular MRSA infections. As a result, there has not been an overexposure of MRSA to chloramphenicol and thus resistance has not yet developed. However, MRSA ocular infections resistant to chloramphenicol treatment have been described ${ }^{10}$ and we observed one such case in the year prior to this study of an 82-year-old lady who presented late with a destructive keratitis that later perforated. MRSA infections in nonocular sites can behave very aggressively and it was suprising that we did not encounter more severe or resistant cases of ocular infections. However, the above example suggests that aggressive strains of MRSA that affect the eye exist in the UK but at the time of writing are very rare.

Chloramphenicol may appear to be the drug of choice but its use is not widespread because of the perceived risks of aplastic anaemia ${ }^{11}$ especially in the USA where it has been withdrawn. However, as Fukuda et al' $\mathrm{s}^{7}$ study demonstrated, chloramphenicol was clinically effective in $81 \%$ of cases with MRSA conjunctivitis and this may gain favour as a first-line choice of antibiotics outside the USA. The choice of antibiotics used in other studies varied but resistance to aminoglycosides and other antimicrobials, particularly ofloxacin, has been well documented. Tazawa and Ooishi's ${ }^{8}$ work on MRSA ocular infections demonstrated increasing resistance to ofloxacin, over time during the 1980's. While vancomycin-resistant MRSA has been described, ${ }^{12}$ this fortunately has not yet been reported in MRSA ocular infections. Vancomycin has been used frequently with success, although in rare instances in-house preparations of higher strength $5 \%$ vancomycin were required. ${ }^{6}$

Underlying medical problems are a common finding in several studies including ours where respiratory, malignant, and cerebrovascular disease was prominent. Fukuda et $a l^{7}$ reported MRSA conjunctival commensals to be three times higher in chronically bedridden patients and 1.5 times greater in patients with anaemia, malignancy, and liver dysfunction when compared with normals. ${ }^{7}$ The high incidence of chronic systemic illness may simply be a reflection that these patients require care in a nursing home or repeated admissions to hospital wards where MRSA colonisation is endemic. This is illustrated by Brennen and Muder ${ }^{13}$ who described episodes of conjunctivitis in a long-term care facility where the majority of patients had severe neurological impairment and where seven of the 19 patients were colonised with MRSA in nonocular sites. Four of our patients were nursing home residents of whom only one was screened for MRSA and was negative.

While the majority of the cases described in this study are predominantly primary MRSA infections, some had occurred postoperatively (patient nos. 7, 16 and 17). It is reassuring that during the period of this study no cases 
Table 2 Summary of studies looking at MRSA ocular infections

\begin{tabular}{|c|c|c|c|c|}
\hline $\begin{array}{l}\text { Author } \\
\text { Year } \\
\text { Country of study }\end{array}$ & $\begin{array}{l}\text { Type of study (no. of } \\
\text { patients) }\end{array}$ & Type of MRSA infections & $\begin{array}{l}\text { Treatment (topical unless stated } \\
\text { otherwise) }\end{array}$ & Other details of note \\
\hline $\begin{array}{l}\text { Ribner }^{21} \\
1987 \\
\text { USA }\end{array}$ & Case series (1) & Conjunctivitis & Not specified & $\begin{array}{l}\text { Retrospective study over } 7 \text { years characterising } \\
\text { MRSA infections in a paediatric unit }\end{array}$ \\
\hline $\begin{array}{l}\text { Ross and Abate }{ }^{22} \\
1990 \\
\text { USA }\end{array}$ & Case report (1) & Conjunctivitis & Vancomycin & $\begin{array}{l}\text { Methicillin-resistant Staphylococcal epidermidis } \\
\text { also isolated }\end{array}$ \\
\hline $\begin{array}{l}\text { Brennen and } \text { Muder }^{13} \\
1990 \\
\text { USA }\end{array}$ & Case series (19) & Conjunctivitis & Systemic ciprofloxacin, vancomycin & $\begin{array}{l}\text { Outcome of } 20 \text { episodes of conjunctivitis in a } \\
\text { long-term care unit. A total of } 17 \text { patients had } \\
\text { severe neurological impairment. Nine were } \\
\text { colonised with MRSA before the onset of } \\
\text { conjunctivitis }\end{array}$ \\
\hline $\begin{array}{l}\text { Insler et } a l^{23} \\
1991 \\
\text { USA }\end{array}$ & Case reports (3) & Postoperative keratitis & Ciprofloxacin & \\
\hline $\begin{array}{l}\text { Eiferman } e t a l^{24} \\
1991 \\
\text { USA }\end{array}$ & Case reports (3) & Keratitis & $\begin{array}{l}\text { Vancomycin used only. Resistant } \\
\text { to aminoglycoides }\end{array}$ & One patient was from a nursing home \\
\hline $\begin{array}{l}\text { Tazawa and Ooishi (In Japanese) } \\
1992 \\
\text { Japan }\end{array}$ & Case series (46) & $\begin{array}{l}\text { Conjunctivitis, keratitis, } \\
\text { endophthalmitis }\end{array}$ & $\begin{array}{l}\text { Olfoxacin, minocycline, netilmicin, } \\
\text { amikacin used. }\end{array}$ & $\begin{array}{l}\text { 10-year analysis with increasing ofloxacin } \\
\text { resistance over time }\end{array}$ \\
\hline $\begin{array}{l}\text { Muder } \text { et }_{a l^{25}} \\
1993 \\
\text { USA }\end{array}$ & Case series (1) & Conjunctivitis & Vancomycin & Describes MRSA infections of healthcare workers \\
\hline $\begin{array}{l}\text { Mitsuda et } a l^{26} \\
1995 \\
\text { Japan }\end{array}$ & Case series (4) & Conjunctivitis & Ofloxacin & $\begin{array}{l}\text { Describes all types of MRSA infections in three } \\
\text { outbreaks in a neonatal nursery }\end{array}$ \\
\hline $\begin{array}{l}\text { Spindel et } a l^{27} \\
1995 \\
\text { USA }\end{array}$ & Case series (28) & Conjunctivitis & Not specified & $\begin{array}{l}\text { All types of MRSA and methicillin-susceptible } \\
\text { infections over } 5 \text { years in a } 120 \text {-bed nursing home. } \\
\text { Patients were typically debilitated. } 62 \% \text { of patients } \\
\text { had an CVA }\end{array}$ \\
\hline $\begin{array}{l}\text { Jernigan } e t a l^{28} \\
1996 \\
\text { USA }\end{array}$ & Case series (1) & Conjunctivitis & $\begin{array}{l}\text { Vancomycin not stated if systemic } \\
\text { or topical }\end{array}$ & $\begin{array}{l}\text { Describes a 7-month outbreak of MRSA } \\
\text { colonisation and infections in neonatal ITU }\end{array}$ \\
\hline
\end{tabular}


Table 2 Continued

\begin{tabular}{|c|c|c|c|c|}
\hline $\begin{array}{l}\text { Author } \\
\text { Year } \\
\text { Country of study }\end{array}$ & $\begin{array}{l}\text { Type of study (no. of } \\
\text { patients) }\end{array}$ & Type of MRSA infections & $\begin{array}{l}\text { Treatment (topical unless stated } \\
\text { otherwise) }\end{array}$ & Other details of note \\
\hline $\begin{array}{l}\text { Saitoh A et al } \\
1997 \\
\text { Japan }\end{array}$ & Case reports (2) & $\begin{array}{l}\text { Endophthalmitis acute } \\
\text { dacrocystitis }\end{array}$ & Vancomycin systemically & $\begin{array}{l}\text { Describes methodology of dose adjustment in } \\
\text { patients on systemic vancomycin treatment }\end{array}$ \\
\hline $\begin{array}{l}\text { Oshima et } a l^{30} \\
1999 \\
\text { Japan }\end{array}$ & Case series (7) & $\begin{array}{l}\text { Scleral buckle infections } \\
\text { Endophthalmitis }\end{array}$ & $\begin{array}{l}\text { Vancomycin. Used via systemic, } \\
\text { intravitreal and subconjunctival } \\
\text { routes in cases of endophthalmitis }\end{array}$ & $\begin{array}{l}\text { MRSA infections associated with patients with } \\
\text { atopic dermatitis }\end{array}$ \\
\hline $\begin{array}{l}\text { Rubinfeld and Negvesky }{ }^{14} \\
2001 \\
\text { USA }\end{array}$ & Case report (1) & $\begin{array}{l}\text { Bilateral keratitis postlaser } \\
\text { in situ keratomileusis }\end{array}$ & Tobramycin, vancomycin & $\begin{array}{l}\text { Patient had positive culture of MRSA from nares } \\
\text { and also had a previous MRSA infection following } \\
\text { abdominal surgery }\end{array}$ \\
\hline $\begin{array}{l}\text { Horil et } a l^{10} \\
2001 \\
\text { Japan }\end{array}$ & Case series (6) & Conjunctivitis & $\begin{array}{l}\text { Benzethonium chloride } 0.02 \% \\
\text { solutions used }\end{array}$ & $\begin{array}{l}\text { Patients were bed-ridden and came from a single } \\
\text { stroke unit }\end{array}$ \\
\hline $\begin{array}{l}\text { Rudd and Moshirfar }{ }^{15} \\
2001 \\
\text { USA }\end{array}$ & Case report (1) & $\begin{array}{l}\text { Keratitis postlaser in situ } \\
\text { keratomileusis }\end{array}$ & $\begin{array}{l}\text { Vancomycin, gentamicin and } \\
\text { ofloxacin }\end{array}$ & \\
\hline $\begin{array}{l}\text { Cosar } e t a l^{31} \\
2001 \\
\text { USA }\end{array}$ & Case series (2) & $\begin{array}{l}\text { Corneal wound infections } \\
\text { postphacoemulsification }\end{array}$ & $\begin{array}{l}\text { Vancomycin and tobramycin. } \\
\text { Systemic levofloxacin }\end{array}$ & $\begin{array}{l}\text { Describes case series of seven corneal wound } \\
\text { infections postphacoemulsification }\end{array}$ \\
\hline $\begin{array}{l}\text { Forster et } a l^{16} \\
2002 \\
\text { Germany }\end{array}$ & Case report (1) & $\begin{array}{l}\text { Keratitis } \\
\text { postphotorefractive } \\
\text { keratectomy }\end{array}$ & $\begin{array}{l}\text { Systemic gentamicin and } \\
\text { clindamycin. Topical erythromycin }\end{array}$ & $\begin{array}{l}\text { Patient had postoperative bandage contact lens } \\
\text { and given ofloxacin drops }\end{array}$ \\
\hline $\begin{array}{l}\text { Kubo et } a l^{32} \\
2002 \\
\text { Japan }\end{array}$ & Case reports (4) & $\begin{array}{l}\text { Acute and chronic } \\
\text { dacrocystitis }\end{array}$ & $\begin{array}{l}\text { Povidone-iodine or vancomycin. } \\
\text { One patient also had dibekacin } \\
\text { sulphate }\end{array}$ & $\begin{array}{l}\text { Patients were treated successfully with a } \\
\text { dacryocystorhinostomy. Postoperative cultures } \\
\text { taken from the nose and conjunctiva were negative } \\
\text { for MRSA }\end{array}$ \\
\hline $\begin{array}{l}\text { Sotozono et } a l^{6} \\
2002 \\
\text { Japan }\end{array}$ & Case series (30) & Conjunctivitis, keratitis & Vancomycin, arbecakacin & $\begin{array}{l}\text { Study also included methicillin-resistant } \\
\text { Staphylococcus epidermidis }\end{array}$ \\
\hline $\begin{array}{l}\text { Fukuda et } a l^{7} \\
2002 \\
\text { Japan }\end{array}$ & Case series (74) & Conjunctivitis & Vancomycin, chloramphenicol & $\begin{array}{l}\text { Investigated prevalence of MRSA and methicillin- } \\
\text { resistant coagulase-negative Staphylococcus } \\
\text { infections on the ocular surface }\end{array}$ \\
\hline $\begin{array}{l}\text { Donnenfeld et } a l^{17} \\
2003 \\
\text { USA }\end{array}$ & Case series (1) & $\begin{array}{l}\text { Keratitis } \\
\text { postphotorefractive } \\
\text { keratectomy }\end{array}$ & $\begin{array}{l}\text { Tobramycin until culture results } \\
\text { were available; then vancomycin } \\
\text { and ofloxacin }\end{array}$ & Case was bilateral \\
\hline
\end{tabular}


of MRSA endophthalmitis had been recorded. However serious infections of postoperative keratitis have been reported particularly after refractive surgical procedures. ${ }^{14-17}$ One of these cases was MRSA positive in the nares and had a past history of MRSA postoperative wound infection of the abdomen. ${ }^{14}$ In our own series, only five patients were screened for nonocular MRSA colonisation of which one was positive. This low rate of swabbing nonocular sites was due to the fact that many of the infections resolved quickly and patients were discharged following treatment in the eye casualty or outpatients before any microbiological results were made available.

MRSA is a significant cause of postoperative morbidity, particularly in patients who have undergone vascular procedures. ${ }^{18}$ There has been much debate on how to tackle the problem. In addition to infection control of outbreaks, screening to rule out MRSA colonisation also needs to be considered. However, issues such as cost effectiveness and staff screening make providing straightforward guidelines difficult, especially in hospital wards where MRSA is now endemic. The British working party on the control of MRSA has provided guidelines but these offer flexibility by allowing individual hospitals to interpret these guidelines in the context of the local situation. ${ }^{3}$ Our own unit screens preoperative patients who are resident in long-term care facilities or who have been in hospital as an in-patient up to 6 months prior to surgery. However, policies vary widely in specialist ophthalmic units in the UK (personal communication). From a review of our database it was clear that there were several cases where MRSA must have been an ocular commensal. There have been several previous studies investigating bacterial flora on clinically healthy conjunctivas preoperatively.7,19,20 These studies have found high rates of positive bacterial growth particularly Gram-positive cocci. More specifically, the rates for MRSA vary. Kato and Hayasaka ${ }^{20}$ report 13/978 (1.33\%) eyes swabbed preoperatively grew MRSA compared with $6.58 \%$ of eyes in Fukuda's study of 1000 asymptomatic eyes.

However, several important unanswered questions remain. Firstly, what is the risk of MRSA colonisation leading to ocular infection, be it primary or postoperative? Does MRSA colonisation in nonocular sites increase the risk of colonisation within the conjunctiva? What are the implications for preoperative screening in an ophthalmic setting?

In summary, to the best of our knowledge, this is the first case series describing MRSA external ocular infections in the UK. We conclude that MRSA is an infrequent cause of external ocular infections in the UK and currently infections are readily treated in most instances with topical chloramphenicol. However, resistance to ofloxacin is widespread. Comparisons with other work show similarities in terms of the type of patients prone to MRSA infections, but there are clear geographic differences in the spectrum of sensitivity and severity of ocular surface MRSA infections that have been reported. This study also highlights the need for further work to determine the relationship between MRSA colonisation and ocular infections. This will assist in formulating guidelines for the screening of patients before ocular surgery.

\section{References}

1 Hryniewicz W. Epidemiology of MRSA. Infection 1999; 27(Suppl. 2): S13-S15.

2 Van Belkum A, Verbrugh H. 40 years of methicillin-resistant Staphylococcus aureus. BMJ 2001; 323: 644-645.

3 Working Party of the British Society of Antimicrobial Chemotherapy, Hospital Infection Society and Infection Control Nurses Association. Revised guidelines for the control of methicillin-resistant Staphylococcus aureus. J Hosp Infect 1998; 39: 253-290.

4 Simcock PR, Butcher JM, Armstrong M, Lloyd IC, Tullo AB. Investigation of microbial keratitis: an audit from 1988-1992. Acta Ophthalmol Scand 1996; 74: 183-186.

5 Andrews JM. The development of the BSAC standardised method of disc diffusion testing. I Antimicrob Chemother 2001; 48(Suppl.1): 29-42.

6 Sotozono C, Inagaki K, Fujita A, Koizumi N, Sano Y, Inatomi $\mathrm{T}$ et al. Methicillin-resistant Staphylococcus aureus and methicillin-resistant Staphylococcus epidermidis infections in the cornea. Cornea 2002; 21(Suppl. 2): S94-S101.

7 Fukuda M, Ohashi H, Matsumoto C, Mishima S, Shimomura Y. Methicillin-resistant Staphylococcus aureus and methicillin-resistant coagulase-negative Staphylococcus ocular surface infection. Cornea 2002; 21(Suppl. 2): S86-S89.

8 Tazawa H, Ooishi M. MRSA ocular infections. Nippon Rinsho 1992; 50: 1122-1126, (in Japanese).

9 Miedziak AI, Miller MR, Rapuano CJ, Laibson PR, Cohen EJ. Risk factors in microbial keratitis leading to penetrating keratoplasty. Ophthalmology 1999; 106: 1166-1171.

10 Horil T, Futamura N, Suzuki Y. Antiseptic treatment of methicillin-resistant Staphyloccocus aureus conjunctivitis. J Infect 2001; 42: 166-169.

11 Doona M, Walsh JB. Use of chloramphenicol as topical eye medication: time to cry halt? BMJ 1995; 310: 1217-1218.

12 Hiramatsu K, Aritaka N, Hanaki H, Kawasaki S, Hosoda Y, Hori $S$ et al. Dissemination in Japanese hospitals of strains of Staphylococcus aureus heterogeneously resistant to vancomycin. Lancet 1997; 350: 1670-1673.

13 Brennen C, Muder RR. Conjunctivitis associated with methicillin-resistant Staphlococcus aureus in a long-term care facility. Am J Med 1990; 88(5N): 14N-17N.

14 Rubinfeld RS, Negvesky GJ. Methicillin-resistant Staphylococcus aureus ulcerative keratitis after in situ keratomileusis. J Cataract Refract Surg 2001; 27: 1523-1525.

15 Rudd JC, Moshirfar M. Methicillin-resistant Staphylococcus aureus keratitis after laser in situ keratomileusis. J Cataract Refract Surg 2001; 27: 471-473. 
16 Förster W, Becker K, Hungermann D, Busse H. Methicillinresistant Staphylococcus aureus ulcerative keratitis after excimer laser photorefractive keratectomy. J Cataract Refract Surg 2002; 28: 722-724.

17 Donnenfeld ED, O’Brien TP, Solomon R, Perry HD, Speaker MG, Wittpenn J. Infectious keratitis after photorefractive keratectomy. Ophthalmology 2003; 110: 743-747.

18 Naylor AR, Hayes PD, Darke S. A prospective audit of complex wound and graft infections in Great Britain and Ireland: the emergence of MRSA. Eur J Vasc Endovasc Surg 2001; 21: 289-294.

19 Watanabe K, Numata-Watanabe K, Hayasaka S. Methicillinresistant Staphylococci and ofloxacin-resistant bacteria from clinically healthy conjunctivas. Ophthalmic Res 2001; 33: 136-139.

20 Kato T, Hayasaka S. Meticillin-resistant Staphylococcus aureus and methicillin-resistant coagulase-negative Staphylococci from conjunctivas of preoperative patients. Jpn J Ophthalmol 1998; 42: 461-465.

21 Ribner BS. Endemic, multiply resistant Staphylococcus aureus in a pediatric population. Clinical description and risk factors. Am J Dis Child 1987; 141: 1183-1187.

22 Ross J, Abate MA. Topical vancomycin for the treatment of Staphylococcus epidermidis and methicillin-resistant Staphylococcus aureus conjunctivitis. DICP 1990; 24: 1050-1053.

23 Insler MS, Fish LA, Silbernagel J, Hobden JA, O'Callaghan RJ, Hill JM. Successful treatment of methicillin resistant Staphylococcus aureus keratitis with topical ciprofloxacin. Ophthalmology 1991; 98: 1690-1692.

24 Eiferman RA, O'Neill KP, Morrison NA. Methicillinresistant Staphylococcus aureus corneal ulcers. Ann Ophthalmol 1991; 23: 414-415.
25 Muder RR, Brennen C, Goetz AM. Infection with methicillin- resistant Staphlococcus aureus amoung hospital employees. Infect Control Hosp Epidemiol 1993; 14: 576-578.

26 Mitsuda T, Arai K, Fujita S, Yokota S. Epidemiological analysis of strains of methicillin-resistant Staphylococcus aureus (MRSA) infection in the nursery; prognosis of MRSA carrier infants. J Hosp Infect 1995; 31: 123-134.

27 Spindel SJ, Strausbaugh LJ, Jacobson C. Infections caused by Staphylocoocus Aureus in a veterans affairs nursing home care unit: a 5-year experience. Infect Control Hosp Epidemiol 1995; 16: 217-223.

28 Jernigan JA, Titus MG, Groschel DH, Getchell-White SI, Farr BM. Effectiveness of contact isolation during a hospital outbreak of methicillin-resistant Staphylococcus aureus. Am J Epidemiol 1996; 143: 496-504.

29 Saitoh A, Jinbayashi H, Saitoh AK, Ohira A, Amemiya T, Etoh $\mathrm{K}$ et al. Parameter estimation and dosage adjustment in the treatment with vancomycin of methicillin-resistant Staphylococcus aureus ocular infections. Ophthalmologica 1999; 211: 232-235.

30 Oshima Y, Ohji M, Inoue $\mathrm{Y}$, Harada J, Motokura M, Saito $\mathrm{Y}$ et al. Methicillin-resistant Staphylococcus aureus infections after scleral buckling procedures for retinal detachments associated with atopic dermatitis. Ophthalmology 1999; 106: 142-147.

31 Cosar CB, Cohen EJ, Rapuano CJ, Laibson PR. Clear corneal wound infection after phacoemulsification. Arch Ophthalmol 2001; 119: 1755-1759.

32 Kubo M, Sakuraba T, Arai Y, Nakazawa M. Dacryocystorhinostomy for dacryocystitis caused by methicillin-resistant Staphylococcus aureus: report of four cases. Jpn J Ophthalmol 2002; 46: 177-182. 